J. G. Harvey, Diana G. Hayes, Patricia A. Heckles, Jivien J. I. Holgate, Kay Hollingsworth, D. H. Horwell, Vivien J. I. Holgate, Kay Hollingsworth, D. H. Horwell, T. M. Jack, G. Jackson, C. G. Jamieson, M. D. Jenkins,
R. C. Johnson, N. K. Jones, R. N. Jones, Roberta M. E. Jones, S. W. Kadleigh, M. J. Kelly, P. W. Kemp,
I. F. Kerr, M. G. Kerr Muir, M. A. La'ajam, D. N. W. Lake, A.J. Laljie, G. S. Lang, Margaret E. Leigh,
C. B. Lessell, M. S. Lewis, B. D. Linaker, E. A. Lloyd, C. B. Lessell, M. S. Lewis, B. D. Linaker, E. A. Lloyd,
Diana M. Lowe, J. C. Lowry, Clare V. McCormick,
R. E. McCune, J. D. MacGuire, R. Maitra, S. Maitra, R. E. McCune, J. D. MacGuire, R. Maitra, S. Maitra,
Louise J. Malbon, R. P. Mandeville, S. P. Marr, M. A. Martin, A. S. G. Mary, J. Michael, M. A. Mohamed,
M. C. Monk, Anne H. Murray, R. H. M. Nanka-Bruce, M. F. H. Nelki, G. C. K. Nkwazi, J. M. A. Northover, I. . . O'Brien, P. H. O'Reilly, Elisabeth W. Paice,
Prior, J. Ragazdeau, R. Pease, Diane M. Price, R. J. Robinson, J. N. Rosenberg, Ann E. Rowlands, P. A. Sackin, I. A. Saunders, J. R. Sauvey, C. S. Sellick,
Barbara L. Skew, K. A. Smales, J. O. Soul, H. W. Steer,
D. G. Stubbing, M. G. St. J. Sutton, D. J. Sydenham, D. G. Stubbing, M. G. St. J. Sutton, D. J. Sydenham, Thompson, J. N. Thorley, M. O. Thorner, Anna-
Maria Tihanyi, P. Tivy-Jones, R. S. Trompeter,
M. S. Turner, A. G. Tyers, S. H. Vincent, M. P. M. S. Turner, A. G. Tyers, S. H. Vincent, $M$. P.
Virapen, N. Walker, A. R. G. Ward, Fiona B. Webster,
A. C. White, N. W W R A. C. White, N. S. Williams, R. G. Wright, Heather W. T. Elias.

The following diplomas were granted jointly with the Royal College of Surgeons of England: DIPLOMA IN CHILD HBALTH.-I. Abraha, Siham

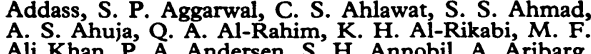
Ali Khan, P. A. Andersen, S. H. Annobil, A. Aribarg,
P. Arulanantham, M. R. Bahl, Ghada M. Bishouty, D. J. Bolitho, J. V. Brooke, Mary F. Brown, Dale A. Marion R. Crouchman, Clare A. Cunningham, A. A. Datoo, J. M. Davies, Astrid Dunsis, D. M. Easton, R. H. Eve, Jayashree A. Firodia, Jean C. Firth, Judith A. Fraser, S. S. Gerber, R. Ghani, A. Greenwood, Helen E. Hughes, H. A. Hunt, S. M. Z. Imam, R. J. G. R. L. Jayakuru, M. de Silva Jayasinghe, Cathleen M. Jennings, Sarah w. J. Jijii, Divya v. Khiroya, v. $P$. Kimati, C. Kirya, A. S. Kulkarni, Nadira H. Lakdawalla, Lee, Sujatha M. Lena, S. W. M. Leung, Q. G. LivingMalcolm, J. S. Martin, Jacqueline S. Maxmin, J. R. Maxwell, H. Meadows, A. D. Mehta, S. T. Meller, J. S. Mortimer, R. N. Morzaria, S. K. Nallainathan, Joyee Nobis, J. R. Norman, M. G. Nutting, Hong G. Parulekar, R. Patalay, S. J. Phillips, A. M. M. Pichanick, J.T. Quil, A.S. F. Rahman, Shubba L. Rao, S. N. Ray, Mary A. Reece, A. D. Revel, D. Roberts-Thomson, Sheila Santamaria, I. P. Q. Scott, M. J. M. SenevirathneBanda, N. P. Shah, B. Singer, N. R. Soma, C. M. M. Stern, D. Stratton, S. L. Tan, G. J. A. Walker, P. W. M. Windsor, Susan E. Wood, Janet G. Yassa. DIPLOMA IN MEDICAL RADIO-DIAGNOSIS.-Joan $\mathrm{K}$. Watters, J. Cripps.

\section{ROYAL COLLEGE OF} OBSTETRICIANS AND GYNAECOLOGISTS

D.OBst. R.C.O.G.-Gillian W. Abbott, R. K Adkinson, Nafeesunissa Ahmed, Mohini Ahuja, Khalida
A. Akhtar, B. A. K. Al-Kazzaz, Judith Allerston, T A. Akhtar, B. A. K. Al-Kazzaz, Judith Allerston, T. Atkinson, E. O. Babatunde, N. B. Bain, Kanagaratnam Balasubramaniam, Jayasri Baneriee, N. M. Bark,
D. S. G. Bath, N. G. MacE. Beattie, C. M. BedfordTurner, A. P. Bennett, Jennifer A. Bent, J. L. Bent, Jill Betheli, R. J. Birts, A. R. Blackburn, R. B. W. F. J. Borchardt, J. F. Bostock, Janet E. Bowen, I. M. Bowles, Josephine C. Boxer, Christine M. Bradley, Jane L. Bradley, W. B. Broadbent, J. B. Broadfield, E. Brogan, Patricia J. Brooks, Susan E. Brown, T. I. S.
Brown, G. M. Browne, I. C. Buchan, M. S. Buckingham, Brown, G. M. Browne, I. C. Buchan, M. S. Buckingham,
J. F. Buckley, A. K. Budd, Frances W. Burns, Ann M. Burroughes, Gillian C. Button, L. D. Byer, D. G. D Champbell, I. B. Campbell, A. G. M. Carless, R. F. Chopra, Bushra R. Choudhry, R. K. L. Chu, M. J. Clark, D. A. Coates, M. B. Coates, G. Constantinides, M. J. Corbin, Dona A. S. L. Corea, M. Coulthard, Cruickshank, R. Dakin, Anne G. Daly, R. J. E. Daniel, J. L. Davies, E. P. Davis, Heather M. R. Davis, M. L. Diament, A. R. Dick, S. Dillon, Dian Donnai, Maureen Dudmesh, Susan A. Dukes, Delia M. Elliott, D. M Elmore, P. Fancourt, J. S. Fenton, Angela M. Field Fitzpatrick, D. P. Fletcher, Hilary M. Forsyth, R. C. Freedman, Hazel J. M. Furtado, R. S. Gale, C. T Garrigan, S. B. T. Gately, Deb Baran Ghosh, I. C. A. Glennie, J. S. Goodall, A. L. Goostrey, D. C. Green, Patricia M. Greenfield, D. I. Grieve, G. J. Griffiths, Hares, K. C. Harvey, W. R. Harvey, J. Harworth,
Ruth J. Heinsheimer, J. J. Henderson, Wendy J.
Higlett, E. W. Hill, P. M. Hill, W. T. Hill, A. V. Hirsh, Raghuveer R. Hoskote, A. Houghton, Jane R. Howard, Huda, Manik Husain, C. P. Innes, Hilary G. Jackson,
P. H. Jackson, R. N. Jeffrey, B. R. Jelfs, A. J. Jenkins, J. A. Jennings, M. A. A. Johnson, Penelope J. Johnson, ones, R. D. Jones, Basant S. Kalsi, P. Kedney, J. C. A. Kehoe, D. H. Kennedy, D. C. Kent, D. W. Kett, P. A. Knoyle, Sarah Korah, Bijoy L. Kundu, Oladapo A. Ladipo, P. M. J. Lake, R. Lancer, N. W. Lees, Jean Lindsay, R. A. Lloyd-Williams, Kathleen S. Lomax, D. S. Lowry, D. T. McCarthy, N. R. MacMcGimpsey, Catherine McGuire, G. McInroy, Eileen P. McKechnie, C. M. Mackie, Chelliah Mahenthiralingam, J. H. D. Mair, Pranab K. Maiti, Valaparla Manorama, R. G. Marriott, N. W. Marshall, G. E. D. Martin,
Rowena M. Mathias, M. H. M. Meeran, R. L. Miller,
P. M. Moloney, K. Monga, C. J. L. Morgan, J. J. Morrice, L. G. Morris, Elizabeth A. Morton, Jessica Moses, M. J. Mowbray, Joydeb Mukherjee, Sindhu Mutch, S. J. Nalliah, Frances M. C. Neilson, A. J. S. Nicholls, J. A. A. Nichols, I. G. Nisbet, G. I. Okonkwo, Pandit, Dinesh Pandya, Audrey M. Parkes, Sarojani Patel, W. D. Paterson, Kalpana Paul, Dorothy A. Payne, Marianne A. Pearce, C. W. G. Peterkin, S. L. Pethick, Pallanyvelu S. Pillay, A. G. Pocklington, Shivashanker Premila, Nandita Purkayastha, R. J. Rand, G. D. Rawes, Zeenat T. Rizvi, A. J. Roberts, G. L. Robertson, W. A. Robinson, R. J. R. Ropner, G. A. W. Ross, T. J.
Rudman, Carol J. Sage, Maduri Sahai, S. Sahi, M. H. Said, Bibhra Saikia, R. J. Salem, Gopalan Sarala, Asha Saxena, Anila V. Shah, D. E. P. Shapland, Margaret S. B. Shearman, Teresa M. Shelley, Fatemeh G. Shiva, Gauri M. Shrestha, Laxmi N. Shrestha, Maniu
Shrivastav, N. Silk, M. J. Silman, P. I. Silverstone, K. R. Simpson, Devendra B. Singh, Meera Sinha, Smith, M. S. Smith, Heather M. Snook, E. H. Speck, Judith A. Spenceley, R. A. E. Spilling, A. E. Stedman, Mahira K. Sukhera, A. Sutton, Margaret Swaddle, R. I. A. Swann, C. R. S. Tait, R. J. Tapper, I. A.
Taylor, I. W. Taylor, R. J. Thew, Karthigesu Thiagarajah, J. W. Thompson, Linda R. Thompson, R. Thrush, J. A. Townsend, Eileen D. Twomey, M. S. M. Verinder, B. R. W. Vickers, Shashi Vohra, Margaret R. T. Watson, T. R. Watson, L. A. Watterson, Linda M. Welberry, M. J. Wellings, R. J. J. Wenger, D. S. White, Grace P. Whitfield, W. J. Wiggins, Carolyn A. Wilkins, Withers, Hazel P. Wood.

\section{Deaths}

Redfern.-On 28 April 1970, suddenly, Arthur Reginald Redfern, M.B., Ch.B., of 3 Compton
Avenue, Parkstone, Poole, and formerly of $\mathbb{W}$ imAvenue, Parkstone, Poole,

Slater.-On 30 April 1970, suddenly, at his home, White House, Forest Road, East Horsley, Surrey, John McD.s.Ed., aged 71.
F.R.C.S.

\section{Corrections}

Thyroid Replacement Therapy

In the article "Combined Thyroxine and Triiodothyronine for Thyroid Replacement Therapy" by Selwyn Taylor, M. Kapur, and Ross Adie. (2 May, p. 270) part of the Acknowledgements section was omitted in error; this should have read as follows:

"Professor I. D. P. Wootton and Miss Leballeur were responsible for the P.B.I. estimations."

\section{Liquor Examination}

In the article "Role of Liquor Examination" by W. Walker (25 April, p. 220) the liquor bilirubin ratio referred to in the Table should have been 1.099 and not 1.009 as stated.

\section{Childhood Bronchitis}

In the article "Urban and Social Origins of (Childhood Bronchitis in England and Wales," by J. R. T. Colley and D. D. Reid (25 April, p. 213), we greatly regret that there were a number of errors. The corrected sentences should have read as follows:

Page 213, para. 1, line 1: "A survey of respiratory disease ... showed a pronounced social class gradient

Page 213, para. 2, line 11: "Parental social class was important in the past ... (Grundy and Lewis-Faning, 1957; Douglas and Blomield, 1958)."

Page 214, para. 7, line 4: "Table II shows that after adjusting for age, height, weight, and

Page 214, Table II third column, second Page: Peak Flow Rate $(1 . / \mathrm{min}$.) $=226$.

Page 214, para. 8, line 3: "The rates

or ... are a little higher among boys." (the remainder of the sentence being deleted).

Page 215, Table III, second column: Total $=5,414$

Page 215, Table III, third column: Total 5,285 .

Page 215, Table IV (heading): "Prevalence $\%)$ of Ear Perforation ...."

Page 215, para. 1, line 1: "The larger samples obtained ... allow a clear compari-

Page 216, para. 3, line 14: “. . . the constancy of the percentage deficit .... in those with the same positive history ..." Expiratory Flow Rate .. Males and Females" Page 216, Table VIII (footnote): "Number of cases are given in parentheses."

Page 217, para. 2, line 1: "This large sur... (Douglas and Biomfield, 1958 ....)."

Page 217, para. 1, line 8: “. . . in Douglas And Blomfield's study

Page 217, para. 5, line 12: “. . . for a Welsh excess in respiratory morbidity .

Page 217, para. 5, line 15: "Without further detailed studies the true reason will remain obs-

References: "Douglas, J. W. B., and Blomfield, J. M. (1958) ..." "Grundy, F., and Lewis-Faning, E. (1957)

The last sentence in the first paragraph of the "Introduction" should have been deleted.

\section{Notice to Authors}

When original articles and letters for publication are not submitted exclusively to the British Medical fournal this must be stated.

Correspondence on editorial business should be addressed to the Editor, British Medical fournal, B.M.A. House, Tavistock Square, London W.C.1. Telephone: 01-387 4499. Telegrams: Aitiology, London W.C.1.

Authors wanting reprints of their articles should notify the Publishing Manager, B.M.A House, Tavistock Square, W.C.1, on receipt of proofs.

\section{Subscriptions}

Members' subscriptions should be sent to the Secretary of the British Medical Association, B.M.A. House, London, or to the Scottish Secretary, B.M.A. Scottish Office, Drumsheugh Gardens, Edinburgh.

Doctors who are not members of the B.M.A. can subscribe to the B.M.f. The rates for doctors resident in the United Kingdom and abroad are given on the first page of the classified advertisements. These include the rate for the North American "Air Express," which is available to both members and non-members of the B.M.A.

\section{Classified Advertisements}

Doctors Abroad.-Copies of the appointment vacancies advertised in the B.M.7. can be sent by airmail on request. Members' rate: the minimum cost is 40 s. for six weeks' supply, for which copies of vacancies in up to five sections of the classified advertisements will be sent. Non-members' rate $60 \mathrm{~s}$. minimum for sir weeks' supply of five headings or less. Additional headings (for members and nonmembers) 10s. each for six weeks' supply. Orders for specific grades in any section canno be accepted. Payment must be prepaid and enclosed with the application.

Details of rates, etc., for classified advertisements appear on the first page of the classified section. 